\title{
THE STORY OF ONE NOUN: \\ “ACT" IN ENGLISH AND UKRAINIAN DICTIONARIES AND DISCOURSES
}

\author{
Mariia Horodylovska \\ Postgraduate Student, Assistant at the Department of Translation Studies \\ and Contrastive Linguistics named after Hryhorii Kochur, \\ Ivan Franko National University of Lviv, Ukraine \\ e-mail: mariia.horodylovska@lnu.edu.ua,orcid.org/0000-0002-8745-8940
}

\begin{abstract}
Summary
The main focus of this article is the analysis of he noun 'act' in the Ukrainian and English langauges. At the first stage of the research the etymology and the semantic structure of the noun is discussed as well as the variety of its meanings registered in explanatory dictionaries. Special attention is paid to the data provided by a New English Dictionary on Historical Principles. At the second stage of the research special attention is paid to the functioning of the noun under study in the legal discourse. The article provides various definitions of the legal discourse suggested within different scholarly approaches. It also discusses its reference to the legislative and institutional discourses. The legislative discourse is viewed as a part of the legal discourse since legislation encompasses the establishment and further implementation of legal acts. The institutional discourse is considered to be an umbrella term covering all types of discourses brought to life by social institutions (e.g. parliament, Congress, etc.).

Finally, this exploratory enquiry seeks to examine similarities and differences in the semantic structure and functioning of the noun under study in English and in Ukrainian and thus provides the context for follow-up articles on the findings in the field of contrastive linguistics.

Keywords: act, dictionary definition, legal discourse, legislative discourse, institutional discourse.
\end{abstract}

DOI: https://doi.org/10.23856/4405

\section{Introduction}

The word 'act' is a frequently occurring lexical unit which functions within different contexts both as a noun and as a verb. In particular, the noun 'act' is highly polysemantic and can be applied in various senses both in the Ukrainian and English languages depending on the type of discourse. Consequently, the proposed two-part discussion focuses: a) on the analysis of the sematics of the noun; b) on the analysis of its functioning in legal discourse in two languages and two legal cultures.

\section{Etymology}

Six English Etymological dictionaries were taken into account to examine the origin and the semantics of the noun 'act'. Having analyzed the selected dictionaries (see Table 1) we may claim that the noun 'act' originates from Latin actūs where it was commonly used to denote 'a thing done'. In 'legal' sense, when used in reference to the legislation issues, it comes from Latin actūm. Due to the historical events in England in XI - XV century, the word 'act' entered English through Medieval French acte. According to the Oxford English Dictionary on 
Historical Principles, the noun 'act' first appeared in 1384 in the works of G. Chaucer in his Middle English poem "The House of Fame" in a sense of a 'thing done'; 'a deed', 'a performance (of an intelligent being)' (the New English Dictionary on Historical Principles, Volume 1, 1884-1928: 91). Online Etymology dictionary indicates that the noun 'act' comes from Latin verb agere which means 'to set in motion, drive, drive forward'; hence 'to do, perform'; figuratively 'incite to action'; 'to keep in movement, stir up' (Online Etymology Dictionary, 2020). According to the Concise Dictionary of English Etymology, the noun 'act' dates back to XIV century when it started to function in the sense 'deed', then in XV century - in the sense 'legislative decree', and 'section of a drama' - in XVII century (the Concise Dictionary of English Etymology, 2003). According to A Short Etymological Dictionary of Modern English, the substantive form 'act' entered English perhaps via Medieval French/French acte, from Latin actum - a thing done (pl. acta, adopted by English for 'proceedings, transactions'), originally the neuter plural of actus, past participle of agere, to (drive, hence) do, but also partly from Latin actus (genitive actus) - a doing, an action. The verbal form 'act' derives from the Latin past participle actus, but was influenced by the noun 'act' (A Short Etymological Dictionary of Modern English, 1959). According to Etymological Dictionary of the English Language, the noun 'act' means a deed, from the Medieval English act, pl. Actes (Table 1).

Table 1

The etymology of the noun 'act' in English discionaries

\begin{tabular}{|l|l|l|}
\hline \multicolumn{1}{|c|}{ Dictionary } & \multicolumn{1}{c|}{ Via } & \multicolumn{1}{c|}{ Definition } \\
\hline $\begin{array}{l}\text { A New English Dictionary } \\
\text { on Historical Principles }\end{array}$ & $\begin{array}{l}\text { French } a c t e \\
\text { Latin } a c t \bar{u} s \text { (in some senses) }\end{array}$ & $\begin{array}{l}\text { 8 meanings } \\
\text { 1) a thing done; } \\
\text { 2) a deed; } \\
\text { 3) a performace. }\end{array}$ \\
\hline Online Etymology Dictionary & $\begin{array}{l}\text { French } a c t e \\
\text { Latin } a c t u s, \text { actūm (originaly } \\
\text { a leal term) }\end{array}$ & $\begin{array}{l}\text { 1) a thing done; } \\
\text { 2) a doing; a driving } \\
\text { impulse, a setting in motion; } \\
\text { a part in a play. }\end{array}$ \\
\hline $\begin{array}{l}\text { The Concise Oxford Dictionary } \\
\text { of English Etymology }\end{array}$ & $\begin{array}{l}\text { Latin } a c t \bar{s} s, \\
\text { Latin } a c t \bar{u} m \\
\text { French } a c t e(p a r t l y)\end{array}$ & $\begin{array}{l}\text { 1) a doing } \\
\text { 2) public transaction. }\end{array}$ \\
\hline $\begin{array}{l}\text { A Short Etymological Dictionary } \\
\text { of Modern English }\end{array}$ & $\begin{array}{l}\text { Medieval French/French } a c t e \\
\text { Latin } a c t \bar{u} m \\
\text { Latin } a c t \bar{u} s\end{array}$ & $\begin{array}{l}\text { 1) a proceeding, a transaction } \\
\text { 2) a thing done } \\
\text { 3) a doing, an action. }\end{array}$ \\
\hline $\begin{array}{l}\text { An Etymological Dictionary } \\
\text { of the English Language }\end{array}$ & $\begin{array}{l}\text { Medieval English } \\
\text { Latin } a c t \bar{m} m \\
\text { Latin } a c t \bar{u} s\end{array}$ & $\begin{array}{l}\text { 1) a deed; } \\
\text { 2) a thing done. }\end{array}$ \\
\hline $\begin{array}{l}\text { Chambers's Etymological } \\
\text { Dictionary of the English } \\
\text { langauge }\end{array}$ & $\begin{array}{l}\text { Latin } a g o, a c t \bar{u} m \\
\text { Greek } a g \bar{o}\end{array}$ & $\begin{array}{l}\text { 1) something done or doing; } \\
\text { 2) a deed or exploit; } \\
\text { 3) a law; } \\
\text { 4)a part of a play. }\end{array}$ \\
\hline
\end{tabular}

The Ukrainian dictionaries register several definitions of the noun 'act' According to the Dictionary of the Ukrainian Language (ed. by Hrinchenko), the noun 'акт' (genetive case akmy) means 1) дія (въ драматическомъ сочиненіи); 2) актъ, документъ (1862) (Hrinchenko, 1958). An Etymological Dictionary of the Ukrainian Language (ed. by Rudnytskyi) provides the 
information that the noun 'act' (акт, act, акть) entered Ukrainian in XVI century; the derived words: актовий, актуальний, -icmь, актыковати, -анье (XV century); актыкація (XVII century) - урочистий обхід, церемонія, обряд; документ. It was used in the sense: окрема подія, церемонія, рітуал, документ (Etymolohichnyi slovnyk ukrains 'koi movy, 1982). In accordance with Etymological Dictionary of the Ukrainian Language, the the senses of 'акт' developed in the following way: 1) 'вчинок; театральна дія', ст. акть (XVII ст.), borrowed from Latin actus - ago 'дію'; 2) ‘документ', ст. акта (мн.), акты 'книги для запису документів' (XVI ст.), borrowed from Latin via Polish; from Latin actum 'розпорядження, протокол', derived from Latin ago 'дію' (Etymolohichnyi slovnyk ukrains 'koi movy, 1982). According to Etymological and Semantic Dictionary of the Ukrainian Language, the noun 'акт' (genitive case aкmy) comes from Latin actūm - дія, мн. Acta - дії, від agere - діяти; акт - документ, протокол, окремий запис; from Latin actum - запис, документ, народне 'бомага', from Lat. робити, діяти; first appeared in the XVII century (Etymolohichno-semantychnyi slovnyk ukrains 'koi movy, 1979).

Thus the noun 'act' both in the English and Ukrainian languages has a common origin; comes from Latin actūs, actūm and means 'a thing done'. In English dictionaries, it was first registered with various interpretations between XI and XV centuries, while in Ukrainian ones it dates back to XV century. The development of different meanings in the English dictionaries was influenced by French, Greek, Medieval English, while in the Ukrainian dictionaries Polish. Common origin explains some similarities in their semantic structure.

\section{Semantic structure of 'act' and its development}

\subsection{The English language}

The semantic structure of the noun 'act' as represented in English and Ukrainian dictionaries displays dynamics of its development. A New English Dictionary on Historical Principles registeres eight different meanings of the noun. According to this dictionary, the first meaning of 'act' is 'a thing done; a deed, a performance' (of an intelligent being); In that sense act was first mentioned in 1384 in a Middle English poem "The House of Fame" by G. Chaucer. E.g. Thorow God we shal do greate actes, for it is he that shal treade downe oure enemies. The second meaning: 'a thing done as a result, practical outcome, or external manifestation of any state, and, whence the state may be inferred' (1751). E.g. Austin: the only objects which can be called acts are the consequences of volitions. The involuntary movements which are the consequences of certain and diseases are not acts. The third meaning: 'a state of accomplished fact or reality as distinguished from subjective existence, intention, possibility, etc' (1398). E.g. But my Reason tells me, God is a pure Act, and therefore How can He suffer any Punishments. The forth meaning: 'the process of doing; acting, action, operation' (1494). E.g. Act of God: action of uncontrollable natural forces in causing an accident, as the burning of a ship by lightning The fifth meaning: 'something transacted in council, or in a deliberative assembly; hence a decree passed by a legislative body, a court of justice, ect' (1593) E.g. You ... Haue caus'd him by new act of Parliament, To blot out me, and put his owne Sonne in. The sixth meaning: 'a record of transactions or decrees; any instrument in writing to verify facts (from Latin actum, pl. acta)' (1535). E.g. Judicial Acts are said to be all those Writings, and matters which relate to Judicial Proceedings, and are sped in open Court at the Instance of one of the Parties Litigant; and being reduced into writing by a Public Notary ... are recorded by the Authority of the Judge. The seventh meaning: 'a performance of part of a play; hence, one of the main divisions of a dramatic 
work, in which a definite part of the whole action is completed' (1613). E.g. Some come to take their ease, And sleepe an act or two. The eighth meaning: 'in the Universities, a thesis publicly maintained by a candidate for a degree, or to show a student's proficiency' (1733). E.g. The Act was last held after long interruption in 1733; in 1856 the name, with all that related to the ceremony, was removed from the Statute-book, and only survives in the appellation Act Term sometimes given to the Trinity Term (A New English Dictionary on Historical Principles, 1884-1928: 91-92).

Having analyzed various senses of the noun 'act' in Oxford Dictionary, Cambridge Dictionary, Longman Dictionary of Contemporary English, MacMillan Dictionary and Collins Dictionary we discovered some additional senses (see Table 2).

Table 2

Senses of the noun 'act' in modern English dictionaries

\begin{tabular}{|c|c|c|c|c|}
\hline $\begin{array}{c}\text { Oxford } \\
\text { Dictionary }\end{array}$ & $\begin{array}{l}\text { Cambridge } \\
\text { Dictionary }\end{array}$ & $\begin{array}{c}\text { Longman } \\
\text { Dictionary } \\
\text { of Contemporary } \\
\text { English }\end{array}$ & $\begin{array}{l}\text { MacMillan } \\
\text { Dictionary }\end{array}$ & $\begin{array}{c}\text { Collins } \\
\text { Dictionary }\end{array}$ \\
\hline $\begin{array}{l}\text { 1) a particular } \\
\text { thing that } \\
\text { somebody does; }\end{array}$ & $\begin{array}{l}\text { 1) something that } \\
\text { you do; }\end{array}$ & $\begin{array}{l}\text { 1) one thing that you } \\
\text { do; }\end{array}$ & $\begin{array}{l}\text { 1) single thing } \\
\text { someone does; }\end{array}$ & $\begin{array}{l}\text { 1) a single thing } \\
\text { that someone } \\
\text { does }\end{array}$ \\
\hline $\begin{array}{l}\text { 2) a law that has } \\
\text { been passed by a } \\
\text { parliament; }\end{array}$ & $\begin{array}{l}\text { 2) behaviour } \\
\text { that hides your } \\
\text { real feelings and } \\
\text { intentions; }\end{array}$ & $\begin{array}{l}\text { 2) a law that has } \\
\text { been officially } \\
\text { accepted by a } \\
\text { Parliament or } \\
\text { Congress; } \\
\end{array}$ & $\begin{array}{l}\text { 2) behaviour } \\
\text { hiding truth; }\end{array}$ & $\begin{array}{l}\text { 2) behaviour that } \\
\text { does not express } \\
\text { their real feelings }\end{array}$ \\
\hline $\begin{array}{l}\text { 3) a way of } \\
\text { behaving that is } \\
\text { not sincere but is } \\
\text { intended to have a } \\
\text { particular effect on } \\
\text { others; }\end{array}$ & $\begin{array}{l}\text { 3) a person } \\
\text { or group that } \\
\text { performs a short } \\
\text { piece in a show, or } \\
\text { the piece that they } \\
\text { perform; }\end{array}$ & $\begin{array}{l}\text { 3) insincere } \\
\text { behaviour in which } \\
\text { you pretend to have } \\
\text { a particular kind of } \\
\text { feeling or to be a } \\
\text { particular kind of } \\
\text { person; }\end{array}$ & 3) performance; & $\begin{array}{l}\text { 3) a law passed by } \\
\text { the government }\end{array}$ \\
\hline $\begin{array}{l}\text { 4) one of the main } \\
\text { divisions of a play, } \\
\text { an opera, etc. }\end{array}$ & $\begin{array}{l}\text { 4) a part of a play } \\
\text { or opera; }\end{array}$ & $\begin{array}{l}\text { 4) one of the main } \\
\text { parts into which a } \\
\text { stage play, opera, etc } \\
\text { is divided; }\end{array}$ & $\begin{array}{l}\text { 4) part of play, } \\
\text { etc. }\end{array}$ & $\begin{array}{l}\text { 4) in a play, } \\
\text { opera, or ballet is } \\
\text { one of the main } \\
\text { parts into which it } \\
\text { is divided }\end{array}$ \\
\hline $\begin{array}{l}\text { 5) performance, } \\
\text { especially on of } \\
\text { several short pieces } \\
\text { of entertainment in } \\
\text { a show; }\end{array}$ & $\begin{array}{l}\text { 5) a law or formal } \\
\text { decision made } \\
\text { by a parliament } \\
\text { or other group of } \\
\text { people who make } \\
\text { the laws for their } \\
\text { country. } \\
\end{array}$ & $\begin{array}{l}\text { 5) a short } \\
\text { performance on } \\
\text { stage or television } \\
\text { by someone who } \\
\text { plays music or tells } \\
\text { jokes; }\end{array}$ & 5) law & $\begin{array}{l}\text { 5) in a show is a } \\
\text { short performance } \\
\text { which is one of } \\
\text { several in the } \\
\text { show. }\end{array}$ \\
\hline $\begin{array}{l}\text { 6) a performer or a } \\
\text { group of } \\
\text { performers. }\end{array}$ & & $\begin{array}{l}\text { 6) a performer or a } \\
\text { group of } \\
\text { performers who } \\
\text { perform together. }\end{array}$ & & \\
\hline
\end{tabular}


All five dictionaries register the meaning of the noun "act" as 1) a thing someone does; 2) a law passed by the official body (Oxford dictionary indicates Parliament; Longman Dictionary of Contemporary English - Parliament or Congress; Collins Dictionary - government); 3) a performance; 4) insincere or hidden behavior. Apart from Cambridge dictionary, all dictionaries register the meaning of "a part of a play or opera"; Oxford Dictionary, Longman Dictionary of Contemporary English, Cambridge Dictionary present the meaning of "a performer or a group of performers.

\subsection{The Ukrainian language}

According to the Universal dictionary of the Ukrainian Language, the noun 'акт' (рl. акти) means 1) in genitive case aкmу - одиничний вияв якої-небудь діяльності; дія, вчинок. Е.g. Здійснити акт агресї̈; 2) in genitive case акта - закон, указ, постанова, які видають уряд, громадська організація або посадова особа. Е.g. Урядовий акт; 3 ) in genitive case акта документ, протокол, запис про який-небудь юридичний факт. Е.g. Передавати справи за актом; 4) in genitive case aкmy - завершена частина драматичного твору або театральної вистави; дія. Е.g. Комедія на три акти (Universal'nyi slovnyk Ukrains'koi movy, 2007: 21).

The senses of the noun 'act' registered in modern Ukrainian dictionaries are slightly different from the senses, which modern English dictionaries include. According to the Dictionary of the Ukrainian Language, the first meaning of the noun 'акт' (genetive case aкmy) is окремий вияв якої-небудь діяльності або якогось процесу; дія, подія, вчинок. Е.g. Обрядовість сватання на Бойківщчині була важливим громадським актом, який передував шлюбу і санкиіонував його (з наук.-попул. літ.); окрема дія, поодинокий вчинок. Е.g. Тепер приходить їхня черга! Було кожному ясно щзо починався головний акт великої трагедії (I. Багряний). The second meaning of the noun 'акт' (genitive case $а к m y)$ : закінчена частина театральної вистави, драматичного твору; дія. Е.g. Найбільи театральна драматична поема "У пущзі", хоча в останньому акті драматизм понижується (М. Драй-Хмара). The third meaning of the word 'акт' (genitive case акma): указ, постанова державного, суспільного значення. Е.g. Акт незалежності - изе продовження і реальна дія Декларації про державний суверенітет Украӥни, логічний підсумок усього суспільного розвитку останніх років (з газ.); офіційний документ, протокол, запис про який-небудь факт наявності або відсутності чогось. Е.g. Здоровань-лісничий заставив скидати стояки на те саме місце, звідки вони були взяті склав акта і поӥхав геть (Григорій Тютюнник). The fourth meaning of the noun 'акт' (genetive case aкmy): урочисті збори у шкільному закладі або в науковій установі у зв’язку з закінченням навчального року, вручення нагород, тощо. Е.g. На випускному акті його урочисто вітали викладачі (П. Колесник) (Slovnyk ukrains 'koi movy, 1970: 158).

Apart from the variety of definitions provided by the Dictionary of the Ukrainian Language, the following types of acts are distinguished: acts of civil status (акти цівильного (громадянського) стану), audit report (акт ревізіi), terrorist act (терористичний акт), business act (дільчий акт) and legal act (нормативний акт) (Slovnyk ukrains 'koi movy, 2010: 158-159).

Large Explanatory dictionary of the Modern Ukrainian Language provides a couple of definitions as well. For instance: 1) окремий прояв якої-небудь діяльності; дія, подія, вчинок; 2) закінчена частина театральної вистави, драматичного твору; дія; 3 ) письмовий указ, грамота, постанова державного, суспільного значення; офіційний документ, протокол про який-небудь факт (акти громадянського стану - записи спеціальними державними органами фактів народження, смерті, шлюбу, розлучення, тощо; акт ревізї - офіційний документ про результати перевірки фінансово-господарської діяльності підприємства, 
організації, установи чи посадових осіб за певний період; 4) урочисті збори в шкільних закладах у зв'язку з закінченням навчального року (Velykyi tlumachnyi slovnyk suchasnoi ukrains 'koi movy, 2001: 11-12).

According to the Dictionary of the Ukrainian Language, the noun 'акт' means 1) (genitive case aкmy) окремий прояв якої-небудь діяльності; дія, подія, вчинок. Е.g. Вольові акти завжди спираються на вміння і навички особистості; 2) (genitive case акту) закінчена частина театральної вистави, драматичного твору; дія. Е.g. Була й новинка Карпенкова “Cуєта”. Перші три акти добрі. 3) (genitive case акта) писаний указ, грамота, постанова державного, суспільного значення. Е.g. А хутко я вам подарую інакиий [перстень], щзоб печаті прикладати до командорських актів; офіційний документ, протокол, запис про який-небудь факт. Е.g. Сів голова на своє місце за столом, звелів рахівникові акта скласти. 4) (genitive case акmy) урочисті збори в шкільних закладах у зв'язку 3 закінченням навчального року. Е.g. Другого дня в школі був акт (Slovnyk ukrains'koi movy, 1970: 28-29).

The semantic structure of the noun 'act' has some divergent features in English and Ukrainian languages. In Ukrainian as well as in English, the first and general meaning of the analyzed noun is 'a thing done' (дія, вчинок). Further development of the semantic structure of the word is a bit different in English where we can trace processes of its specialization. In both languages the similar transference of the unit of nomination to the legal and theatrical spheres occurred paralelly and the word developed similar specialized senses. One more similar sense can be considered the result of the generalization as the 'act' obtained the sense of a public ceremony, official event both in the English and Ukrainian. Basically, the definitions included into studied English and Ukrainian dictionaries are the same and display the same tendencies in the development of their semantic structure, in particular in reference to the sphere of law, though dictionary entries of English dictionaries provide more specialized senses like those referring tos a hidden behaviour or a group of performers.

\section{The word act in Anglophone and Ukrainian discourses}

The polysemantic nature of the noun 'act' explains its frequent use in different types of discourses. For instance, everyday discourse, theatrical discourse, political discourse, etc. Most commonly 'act' is used in legal discourse.

Law plays a vital role in any well-developed society. Law and legal language are interconnected. Law is verbalized using the language of law. The language of law and how it is used by lawyers and those who deal with jurisprudence is characterized by its complexity. Legal texts make the basic component of legal discourse as the latter can be defined as 'a connected sequence of statements that are subject to the same formation system (Foucault, 1996). The main characteristic features of legal discourse include the following: 1) informative function, as legal texts render information; 2) prescriptive function, as legal texts are direct or indirect orders to the recipient to perform certain actions or to refrain from committing them; 3 ) declarative function which is performed through the proclamation of certain social and legal designations (mainly used by a testator to distinguish a person with no implementation of the name of such person often as a word of limitation) and ideas; 4) reasoning function that is inherent in legal discourse, among which the central types are various types of complaints, statements of claim, recalls of the statement of claim and legal decisions, the communicative aim of which is to justify the reaction of a person to a particular situation demonstrating one or another position (Alontseva, Ermolova, 2018). 
Legal discourse is an important subtype of Institutional discourse. Institutional component is an indispensable element of the mechanism of development of a society (Andreichuk, 2011) and is commonly defined as "a communication within the established social institutions of the society" (Dijk, van, 2008). It is also defined as the type of discourse "produced in social institutions that presuppose communication as a constituent part of their organization" (Sheihal, 2002). The communication within institutions is viewed as "a stable system of status-role relationships that have developed in the communicative space of the vital activity of a particular social institution" (Rusakova, 2008) and consequently, institutional discoursepresents "a specialized clichéd type of communication among people, who might not know each other in person, but should communicate in accordance with the regulations of this community" (Karasyk, 2002: 292). Institutional discourse encompasses social interactions (and thus language) that are situated in settings (though not necessarily "physical" locations) recognizable as "institutional" or what some simply call "work-related" (Ehrlich, Romaniuk, 2013).

Thus institutional discourse is produced by a social community. In the sphere of jurisprudence it should be first and foremost a legal authority, an empowered body, e.g. parliament in Great Britain, The United States Congress in the USA, etc. The latter is the bicameral legislature of the federal government of the United States and presents a social institution, where the functions and the roles of its participants are clearly defined. Social institutions formulate a set of established and sanctioned rules of conduct of the individual in society (Hertzler, 1929: 69). Such institutions are the forms of well-organized human relationships, focused on the establishment of common will (Hertzler, 1929: 256).

Act in its legal context is implemented in institutional discourse. For example, U. S. Congress is a legal authority, which issues acts. E.g. Sec. 102. Except as otherwise provided in this Act, for so long as they continue in the nonimmigrant classes enumerated in this section the provisions of this Act relating to ineligibility to receive visas and the exclusion or deportation of aliens shall not be construed to apply to nonimmigrants - (Immigration and Nationality Act of 1952: 173).

The example of the Ukrainian institutional discourse is taken from the Constitution issued by its legislative body, Verkhovna Rada: Конституція України має найвищу юридичну силу. Закони та інші нормативно-правові акти приймаються на основі Конституції України і повинні їй відповідати (Konstytutsia Ukainy, 1996).

Legal discourse is a part of institutional discourse as legal communication is characterized by its institutionality (Alontseva, Ermoshin, 2018). The participants in legal discourse have their roles and the norms they should follow. The participants of legal discourse act in accordance with different legal authorities (Palashevskaya, 2010). Thus, the legal discourse has its aim, concrete participants and well-organized speech situation. This type of discourse functions in different spheres: 1) court hearings; 2) communication (e.g. attorney vs. client; notary vs. client, etc.); 3 ) an oral interrogation of a witness; 4) legislative documents (laws, contracts, agreements); 5) court records and court decisions (Koval, 2006: 87-97). E.g. Sec. 2 That there shall be levied, collected, and paid a tax of \$8 for every alien, including alien seamen regularly admitted as provided in this Act, entering the United States: Provided, That children under sixteen years of age who accompany their father or their mother shall not be subject to said tax (Immigration Act of 1917: 875). Е.g. ... а також форма заповіту і акта його скасування визначаються правом держави, у якій спадкодавець мав постійне місие проживання в момент складання акта або в момент смерті (Zakon Ukrainy “Pro mizhnarodne pryvatne pravo”).

In both languages, 'Act' is most commonly used in the legislative discourse, which can be viewed as a subdivision of the legal discourse. Legal acts are part of the legislation. Legal 
acts are texts of legal documents, which are of primary importance for the successful development of any society. Both in the Ukrainian and Anglophone legislative discourses, the noun 'act' most frequently occurs in the titles of legislative documents. But in the Ukrainian legislative discourse the empowered authorities use the noun 'law' to entitle the act issued by Verkhovna Rada of Ukraine, while in the American legislative dicsourse, the Congress applies the noun 'act' which basically means law thus terminologic difference arises. E.g. The President is permitted to veto specific legislative acts, but Congress has the authority to override presidential vetoes by two-thirds majorities .... (US Constitution, 1787). In the Ukrainian legislative discourse: Президент України зупиняє дію актів Кабінету Міністрів України з мотивів невідповідності иүій Конституції з одночасним зверненням до Конституційного Суду Украӥни щзодо їх конституціийності (Konstytutsia Ukainy, 1996).

\section{Conclusions}

The noun 'act' was borrowed from Latin actūm, actūs and had a long history of its semantic structure development. Its origin was influenced by French, Green, Medieval English and within its development - by Polish in the Ukrainian language. Being registered first between the 11 th and 14th centuries, 'act' was used in a sense of 'a thing done'. Throughout its history, the semantic structure of the noun 'act' developed thus modern Ukrainian and English dictionaries register a lot of senses which can be grouped round the following semes: 1) a thing done, a single thing someone does; 2) a document, a decree, a protocol, a law established by empowered body; 3) part of a performance. Modern English dictionaries also register the sense "a hidden behaviour, the behaviour that does not reveal your real feelings", while Ukrainian dictionaries provide the sense "a public ceremony, an official event".

The noun 'act' most commonly occurs in legal discourse where it can function in two senses: 1) a particular thing that somebody does; 2) a law that has been passed by the government. In the legislative discourse, which is considered to be a subtype of the legal the noun under study is used in the first sense. US Congress as a legislative body in the hierarchical system of the American society and Verkhovna Rada of Ukraine as a legislative body in Ukraine are viewed as social institutions, which generate legislative discourse. Verkhovna Rada of Ukraine establishes acts in the form of laws, which in the very names include the noun "law", e.g. Law of Ukraine "On International Commercial Arbitration, Law of Ukrain "About private international law", etc., while US Congress establishes laws, some of which in the very name include the noun "act", e.g. Immigration Act of 1952, Chinese Exclusion Act of 1882, etc).

\section{References}

Andreichuk, N. I. (2011). Semiotyka linhvokul'turnoho prostoru Anhlii kintsia XVII ctolitia [Semiotics of the linguistic and cultural space of England in the late XV-early XVII centuries]. Lviv: Vydavnytstvo L'vivs 'koi politehniky. [in Ukrainian]

Etymolohichnyi slovnyk ukrains'koi movy, (1982) [Etymological dictionary of the Ukrainian language]. Kyiv: Naukova dumka. Tom 1 http://history.org.ua/LiberUA/EtSlUkrM_1982/ EtSlUkrM_1982.pdf [in Ukrainian]

Etymolohichno-semantychnyi slovnyk ukrains'koi movy, (1979) [Etymological and semantic dictionary of the Ukrainian language] / Mytropolyt Ilarion; za red. Y. Mulyka-Lutsyka. Instytut doslidiv Volyni. Vinnipeh: Volyn'. Ch. 39. T. 1: A-D. http://irbis-nbuv.gov.ua/cgi-bin/ua/elib.exe 
$Z 21 I D=\& I 21 D B N=U K R L I B \& P 21 D B N=U K R L I B \& S 21 S T N=1 \& S 21 R E F=10 \& S 21 F M T=$ online_book\&C21COM=S\&S21CNR=20\&S21P01=0\&S21P02=0\&S21P03=FF=\&S21STR= ukr0001856. [in Ukrainian]

Zakon Ukrainy "Pro mizhnarodne pryvatne pravo" [Law of Ukraine "On international private law”] https://zakon.rada.gov.ua/laws/show/2709-15\#Text. [in Ukrainian]

Karasyk, V. (2002). Yazykovyi kruh lychnos 't'kontsepty, dyskurs [The linguistic circle: fondness concepts, discourse]. Volhohrad: Peremena. [in Russian]

Komunikatyvno-prahmatychni aspekty yurydychnoho dyskursy. Vykladania anhliys'koi movy iak movy fahu v konteksti hlobalizatsii universytetc'koi osvity, (2006) [Communicative and pragmatic aspects of legal dicsourse: Teaching English as a professional language in context of globalization of university education]. Lviv. Vyp. 1. [in Ukrainian]

Konstytutsia Ukainy, (1996) [Constitution of Ukraine]. https://zakon.rada.gov.ua/laws/ show/254к/96-вp\#Text

Kun'ch, Z. (2007). Universal'nyi slovnyk Ukrains'koi movy [Universal dictionary of the Ukrainian language].Ternopil: Navchal'na knyha - Bohdan. [in Ukrainian]

Slovnyk ukrains 'koi movy (red. B. Hrinchenko), (1958) [Dictionary of the Ukrainian language] http://hrinchenko.com. [in Ukrainian]

Slovnyk ukrains 'koi movy, (1970) [Dictionary of the Ukrainian language]. Kyiv: Vydavnytstvo Naukova dumka. Tom 1. (A-B). [in Ukrainian]

Sheihal, E. (2002). Semyotyka polytycheskoho dyskursa [Semiotics of political discourse]. M., Volhohrad: Peremena. [in Russian]

Velykyi tlumachnyi slovnyk suchasnoi ukrains 'koi movy, (2001) [Large explanatory dictionary of modern Ukrainian language]. Kyiv: Irpin': VTF “Perun”. [in Ukrainian]

Alontseva, N., Ermoshin, Y. (2018). Special aspects of working with the lexical level of legal discourse texts in the English and Russian languages. RUDN University. RUDN Journal of Language Studies, Semiotics and Semantics. Vol. 9. No. 2. P. 365-378.

An Etymological Dictionary of the Ukrainian Language, (1982) / Jaroslav B. Rudnyc'kyj. Winnipeg; Ottawa. Vol. 2. http://irbis-nbuv.gov.ua/cgibin/ua/elib.exe?Z21ID=\&I21DB$N=U K R L I B \& P 21 D B N=U K R L I B \& S 21 S T N=1 \& S 21 R E F=10 \& S 21 F M T=$ online_book $\& C$ $21 C O M=S \& S 21 C N R=20 \& S 21 P 01=0 \& S 21 P 02=0 \& S 21 P 03=F F=\& S 21 S T R=u k r 0001504 \_1$ An etymological Dictionary of the English language Walter https://archive.org/details/etymologicaldict00skeauoft/page/6/mode/2up

Cambridge Dictionary, (2020). https://dictionary.cambridge.org

Chambers's Etymological Dictionary of the English Language, (1874). https://i2i.org/wp-content/uploads/2017/11/1874_Chambers_Etymological.pdf

Collins Online Dictionary, (2020). https://www.collinsdictionary.com

Dijk, T., van (2008). Discourse and Power. New York: Palgrave Macmillan.

Ehrlich, S., Romaniuk, T. (2013). Discourse analysis. In R. Podesva \& Devyani (Eds.), Research methods in linguistics. Cambridge, UK: Cambridge University Press. P. 466-499.

Foucault, M. (1996). Archeology of knowledge. Kiev: Nika-Center. [in Russian].

Hertzler, J. (1929). Social Institutions. New York: McGraw-Hill Book Co.

Immigration Act of 1917 (1917). https://www.govinfo.gov/content/pkg/STATUTE-66/pdf/STATUTE-66-PgA72.pdf

Immigration and Nationality Act of 1952. https://www.govinfo.gov/content/pkg/STATUTE-66/ pdf/STATUTE-66-Pg163.pdf

Longman Dictionary of Contemporary English, (2020). https://www.ldoceonline.com

Online Etymology Dictionary, (2020). https://www.etymonline.com 
Origins: A Short Etymological Dictionary of Modern English, (1959). https://cmc.marmot.org/ Record/.b1247910x

Oxford English Dictionary, (2020). https://www.oxfordlearnersdictionaries.com

A New English Dictionary on Historical Principles. Retrived from (1884-1928). http://onlinebooks.library.upenn.edu/webbin/metabook?id=newenglishdictionary

Palashevskaya, I. (2010). Functions of legal discourse and actions of its participants. Izvestiya Samara Scientific Center of the Russian Academy of Sciences, 12 (5(2)). P. 535-540. [in Russian].

Rusakova, O. (2008). PR-Discourse: Theoretical and methodological analysis. Ekaterynburg. [in Russian].

The Concise Oxford dictionary of English Etymology, (2003). https://www.oxfordreference. $\mathrm{com} /$ view/10.1093/acref/9780192830982.001.0001/acref-9780192830982-e-138? rskey $=V V K-$ 2 Ma\&result $=138$

U.S. Constitution, (1787). https://www.govinfo.gov/content/pkg/GPO-CONAN-1992/pdf/GPOCONAN-1992-6.pdf 